International Journal of Child, Youth and Family Studies (2017) 8(3-4): 26-58

DOI: http://dx.doi.org/10.18357/ijcyfs83/4201718000

\title{
LOOKED AFTER CHILDREN'S PERSPECTIVES ON BOOKS BEING DELIVERED TO THE HOME DURING THE LETTERBOX CLUB SCOTLAND PROJECT
}

\section{Andy Hancock and Juliet Hancock}

\begin{abstract}
The low educational achievement of looked after children - children in the care of a local authority — is well documented in the United Kingdom and internationally. However, official statistics do not reveal the nuances of individual children's lived experiences nor children's agency. This article gives weight to children's perspectives, and reports on the views of looked after children aged 7 to 10 in Scotland during the Letterbox Club project. It specifically investigates children's perspectives of reading practices in the home and their responses to books delivered to them over a 6-month period. Data were gathered from 3 distinct but interrelated phases of the research: (a) literacy profiles completed by the children in collaboration with their carer(s), (b) children's comments on evaluation sheets contained in each of the six parcels, and (c) individual conversations with children at the end of the project. The findings reveal the heterogeneous nature of looked after children with multifarious reading proficiencies and reading habits and routines. The children made choices about where and when they read and with whom, expressing opinions about books and authors and using the contents of the parcels to take action and gain greater ownership of their own learning. Finally, the contested nature of children's agency is discussed, as well as the implications for future research involving looked after children.
\end{abstract}

Keywords: looked after children Scotland, reading practices, agency, home literacy

Acknowledgements: This evaluation of the Letterbox Club Project, Scotland, was funded by Booktrust. We gratefully acknowledge the participation of all the children, carers, and professionals involved in this research. We would also like to thank Dr Moira Leslie for her part in the fieldwork and data analysis.

Andy Hancock (the corresponding author) is a Senior Lecturer at the Institute of Education, Teaching \& Leadership, Moray House School of Education, University of Edinburgh, Holyrood Road, Edinburgh EH8 8AQ, Scotland, UK. Email: andy.hancock@ed.ac.uk

Juliet Hancock is a Teaching Fellow at the Institute of Education, Teaching \& Leadership, University of Edinburgh. 
Many studies have reported on the low educational achievement of looked after ${ }^{1}$ children and young people in Scotland (Scottish Parliament, 2012; Scottish Government, 2016), the wider United Kingdom (UK; Sebba et al., 2015), and internationally (O’Higgins, Sebba, \& Luke, 2015) ${ }^{2}$. All provide considerable evidence that looked after children face significant social, cultural, and institutional barriers that impede their success in school education. This is as a result of numerous interrelated factors including transitions to different schools and the need to develop new relationships, high incidences of absenteeism, instances of challenging behaviour and exclusion, low expectations from teachers, and encounters with racism ${ }^{3}$ and bullying (Centre for Excellence for Looked After Children in Scotland, 2016; Driscoll, 2013; Simkiss, Stallard, \& Thorogood, 2013). Looked after children are also more likely to have additional support needs than children in the general population (Scottish Government, 2015a) and, as a group, have lower literacy levels than their peers (Poulton, 2012; Sebba et al., 2015). Cundy and Duffy (2009) showed that there is considerable variation in Scotland in how looked after children are supported to achieve the best possible education.

Despite acknowledged trends, Berridge (2007) cautioned against researchers' and policymakers' use of insufficient and simplistic explanations about low academic achievement among looked after children. For example, despite the many challenges, looked after children can achieve very good educational outcomes (Her Majesty's Inspectorate of Education, 2008). Therefore, Winter (2006) argued that greater attention needs to be given to broader sociological perspectives, the intersectionality of childhood identities, and the sociocultural aspects of the looked after setting. Moreover, increasing numbers of children are coming into care as a result of austerity and rising poverty (Puffet, 2015) and looked after children are living in circumstances that have become increasingly diverse. At the same time, the potential pathways through the care system for some children are not clear-cut in terms of permanence of care (Boddy et al., 2014). Arrangements include legally permanent adoption; temporary, more long-term, or permanent foster care; kinship care (living with a relative); living with birth parent(s); and planned shared care. For definitions and further detail both on these arrangements and on the proportion and attainment of looked after children by accommodation type, see Mathers, Hardy, Clancy, Dixon, and Harding (2016), and Scottish Government (2017). Sebba and colleagues (2015) showed that children who had entered foster or kinship care at an earlier age made better progress educationally than those who were older at age of entry, demonstrating that care could provide an environment more conducive to

\footnotetext{
${ }^{1}$ The term "looked after" introduced by the Children Act 1989 in England and Wales, and used within the Children (Scotland) Act in Scotland is used in this article to refer to children in the care of local authorities. This includes care by relatives (kinship care), by foster carers, or at home with birth parent(s); and in residential care homes, residential schools, or secure units. For proportions of each care arrangement in Scotland refer to Her Majesty's Inspectorate of Education (2008).

${ }^{2}$ Evidence that looked after children lag behind their peers in educational achievement is gained from measures such as examination grades, literacy and numeracy assessments, and attendance and exclusions.

${ }^{3}$ Black and minority ethnic groups are overrepresented compared to the general population of looked after children in England (Thoburn, Chand, \& Procter, 2005).
} 
International Journal of Child, Youth and Family Studies (2017) 8(3-4): 26-58

learning than did their prior circumstances. This may have an important bearing on children's agency and their engagement with books.

At present there is scant research that looks beyond the data on educational outcomes and considers looked after children's agency. The aim of this article, therefore, is to get behind the official statistics and provide insights into looked after children's lived experiences with reading in the home and their own views of receiving books during the Letterbox project.

\section{Policy Context}

The Scottish Government has invested in a number of initiatives targeting "vulnerable" families in order to raise literacy standards and address the poverty gap (Scottish Government, 2010a), with a particular emphasis on looked after children. Policy directions such as the Education (Additional Support for Learning) (Scotland) Act 2004 (amended in 2009) and Getting It Right for Every Child in 2008 have introduced frameworks to improve support to looked after children in school and beyond the school gates (Scottish Government, 2008; Scottish Government, 2010b). With all of this in mind, Dymoke and Griffiths (2010) surmised that looked after children require additional educational support with transitions and during the long holiday break, when there is an observed "summer dip" in their academic progress. Furthermore, evaluations of paired reading schemes involving carers have shown to be effective in improving literacy and engagement in learning (Osbourne, Alfano, \& Winn, 2010). Such considerations motivated the University of Nottingham to develop the Letterbox Club project in 2003 in partnership with local authorities.

\section{The Letterbox Club}

The Letterbox Club sends personalised parcels containing books, stationery, and maths games to children's homes once a month for 6 months (June to November). As space does not allow a detailed analysis of all the resources in the parcels, this article focuses primarily on reading practices and children's responses to the books in the parcels. The expectation is that the parcels will encourage children to engage more with reading, do more numeracy activities, and write and draw more frequently. Additionally, the resources aim to help children and carers build their relationships by increasing the amount of time they spend interacting with each other through sharing the books.

Previous research investigating the impact of the initiative on children's reading skills include studies in England (Griffiths, Dymoke, \& Comber, 2009), Wales (Griffiths \& Comber, 2011), and Northern Ireland (Winter, Connolly, Bell, \& Ferguson, 2011). These evaluations provided evidence that the children who participated in the Letterbox Club saw significant improvement in their reading accuracy and comprehension scores over a 6-month period. However, concerns were expressed about the validity of such quantitative measures conducted without a control group to compare progress against (Winter et al., 2011). Instead, in Scotland, the inquiry shifted to a qualitative approach using case studies in order to provide rich accounts of children's own lived experiences with literacy in the home environment. The data presented in this 
International Journal of Child, Youth and Family Studies (2017) 8(3-4): 26-58

article are drawn from a larger evaluative project and body of fieldwork providing in-depth case studies (Hancock \& Leslie, 2014).

\section{Children's Reading at Home}

Over the last three decades, there has been an increasing understanding that literacy is not simply a narrow cognitive skills-based process gained in school, and that the meanings of literacy are co-constructed and determined by the family contexts in which children are socialised (Hancock, 2008; Heath, 1983; Weinberger, 1996). Rogoff (1990) used the term "guided participation" to stress the active role of children in both observing and participating in routine practices around texts alongside adults, in order to support new understandings. Gee (1990, p. 43) believed that the very texture of these more widely situated practices involves not only dialogue and interaction around texts, but also the inculcation of values and beliefs about what counts as literacy. This sociocultural perspective of literacy learning informs this study, which attends in particular to children's lived experiences, their relationships with others, and the diverse nature of their care contexts. These interwoven features involve the home literacy environment, the role of significant adults and siblings, family narratives, independent reading, and practices such as children's participation in the selection, choice, and quality of reading materials. All of this helps to shape children's literacy acquisition and meaning-making.

Many looked after children are originally from disadvantaged homes (Mathers et al., 2016). The reasons for this are complex and intertwined. They range from the previously cited barriers to success in school, to chaotic home experiences in their early lives, often involving poverty, problems with neglect and abuse, or dealing with a parent's alcohol and substance abuse (Simkiss et al., 2013). Such factors as parents' emotional capacity for family interaction, attachment difficulties, limited shared book reading, difficulty finding a quiet place to read, and availability of good quality reading materials can all affect children's exposure to literacy and their capacity to learn (Cameron, Connelly, \& Jackson, 2015; Lang et al., 2016). With the above in mind, it is not surprising that research has indicated that looked after children are already behind in their language development during the preschool years (Pears \& Fisher, 2005) whilst Pears, Heywood, Kim, and Fisher (2011) reported on looked after children's gaps in prereading skills, such as poor phonological awareness, on entry to school.

At the same time, some contributors to the discussion on learning and home environments have cautioned against making polarised and deficit interpretations about these low-income and less advantaged environments (Cole, 2011; Smyth \& Wrigley, 2013). Although not focusing on looked after children, the Growing Up in Scotland (Melhuish, 2010) longitudinal research discovered that while sociodemographic family factors such as parents' education and income are important, the extent to which families engage with their children in such home learning activities as regularly reading stories, looking at books, and playing games exerts a greater and independent influence on children's learning. These pursuits can have profound influence on children's attitudes to reading and responses to texts in the home. Melhuish's findings echoed those of Sylva, 
Melhuish, Sammons, Siraj-Blatchford, and Taggart (2004), who suggested that positive parenting and parents' participation in literacy practices with their children in the home can alleviate some of the effects of disadvantage. At the same time their study on effective preschool education showed that higher-quality preschool settings can promote greater resilience in young "at risk" children, particularly when competent and caring adults engage in "sustained shared thinking" with children in order to develop and extend their understanding.

A wide range of studies have investigated national intervention programmes to enhance literacy as a supportive factor in the development of preschool children who are "at risk" due to environmental and individual factors. These evaluations of government-sponsored programmes include Head Start in the United States (Chambers, Cheung, Slavin, Smith, \& Laurenzano, 2010) and Sure Start in the UK (Melhuish, Belsky, MacPherson, \& Cullis, 2011). Chambers et al.'s (2010) extensive review of the effectiveness of Head Start programmes included children's enhanced phonological awareness and print or book knowledge as a result of different types of interventions such as provision of resources, shared book reading, dialogic reading, and parent or carer engagement. Hall et al. (2009) noted that the capacity to cope with adversity depends heavily on intellectual resources. Therefore, if these interventions can have a beneficial effect on children's cognitive development, then such intellectual development can contribute in important ways to children's well-being and resilience. These studies do not relate specifically to looked after children but there is reason to believe that the same is true for this group, as they are also "at risk" children.

There have been a number of small-scale literacy intervention programmes to support reading with looked after children in the UK. These include making connections with libraries (Vincent, 2004), storytelling (Stevens, Kirkpatrick, \& McNicol, 2008), carers' involvement in children's reading (Brodie, 2005), and promoting positive reading environments (Finn, 2008). All pointed to improved reading confidence and a positive impact on children's reading attitudes, whereas the evaluation of the Reading Champions Project (City of Edinburgh Council, 2010) noted the strong links between storytelling, literacy skills, positive attachments, and the development of resilience.

However, the Letterbox Club project takes a different stance and explores how children in foster and kinship care engage with texts and their concomitant responses including their tastes, preferences, and ideas. These texts include a range of genre such as audiobooks and literature associated with popular culture (Marsh et al., 2005; Alvermann, 2011). Fry (1985), who analysed children's identities as readers, talked of children seeing themselves as readers and being seen as readers where ownership of books and talking about stories gives children status in the world. In this way possession of a book is not simply about ownership but also about taking pleasure in being able to show that you are a reader. The Letterbox Club supports this interaction of ownership, identity, and pleasure as the children are in receipt of personalised parcels delivered to their home. The children can then engage with a range of texts for a variety of purposes, and unlike school 
books, they are to keep and use as they wish, so they can make choices and return to their favourite books (Dymoke \& Griffiths, 2010).

Regular reading outside of school is now widely accepted as crucial to children's educational achievement and personal growth (Clark, 2014). Moreover, politicians and policymakers consider enhanced literacy standards as leveraging for social change and combating social exclusion (Scottish Government, 2010a). Krashen (2004), a strong advocate for voluntary reading, suggested that for children, being regularly engaged in reading at home augments a myriad of literacy skills including lexical growth, reading fluency, and gaining knowledge of different reading strategies to suit particular purposes such as perusing, browsing, skimming, scanning, and glancing. More practice in reading also leads to improvements in writing abilities as children internalise essential skills of spelling, syntax, and punctuation and absorb the conventions of expression, narrative, and story structure. Children are then able to use these ideas and understandings to generate their own writing (Glazzard \& Palmer, 2015).

Although not a homogeneous group, reading for pleasure may have added significance for children who are looked after, as children's literature plays a powerful role in shaping how readers think about themselves and the world in which they live (Levy, 2011). Stories provide opportunities for escapism and entering into imaginary worlds that are far removed from the realities of children's everyday lives. Readers can also develop empathy with fictional characters and an emotional attachment to "others" (see Kirkpatrick, 2012 for details of the cathartic effects of stories and their positive contribution to children's well-being). At the same time books can encompass and extend the possibilities of human experience and introduce children to other times, places, and cultures as well as validating the reader's own experience.

Extensive reading not only feeds imagination and creativity but also inculcates healthy attitudes to reading and an appreciation that reading is a rich source of relaxation and enjoyment. In contrast, disengaged readers tend to avoid reading, which may have a negative impact on children's confidence and self-esteem (Cairns \& Stanway, 2004). These different patterns of reading engagement are reminiscent of Stanovich's (1986) "Matthew effect" where the gap between good readers and less able readers gets wider over time as independent readers gain more exposure to print and thereby process more information, acquire wider vocabularies, and are more able to access the school curriculum. That said, the individuality of looked after children means there will be fundamental differences in the developmental trajectories of their reading abilities; of course, family contexts and motivation are also critical to reading engagement (Paratore \& Dougherty, 2011).

Foy and Mann (2003) showed that the conditions that can provide looked after children with literate cultural capital can change over time as they respond to different care arrangements. This can be dependent on the age of the child. The collected literature makes a powerful case for ensuring that looked after children have contact with consistent and stable caregiving in environments where they can begin to trust adults and form consistent and secure relationships 
International Journal of Child, Youth and Family Studies (2017) 8(3-4): 26-58

(Mathers et al., 2016). Care arrangements that offer opportunities for children to participate in singing songs and sharing rhymes and stories provide social and emotional benefits. These interactions can have a lasting impact on the child's engagement with literature and their literacy development. The importance of carers and other significant adults in looked after children's lives cannot be underestimated. However, the focus of this present study is aimed towards investigating the heterogeneity of looked after children's experiences with reading, their opinions about the books delivered to the home, and their professed uses of the texts.

\section{Research Methodology}

How we think about research with looked after children brings into sharp focus a number of methodological challenges and ethical quandaries. Some scholars point to the problematic and time-consuming nature of navigating a succession of gatekeepers who are protective of children (Heptinstall, 2000; Hayes, 2005). Others have attempted to ensure that any potential gains from the research are finely balanced against risks to participants (Stewart, 2008).

New policy agendas and practical measures put in place to safeguard children considered vulnerable means gaining access to looked after children for research purposes is not straightforward nor a matter to be taken lightly. Rather, it involves a combination of shared ethical standards throughout the research process, sensitive research planning and design, treating children with dignity and respect, and thoughtful negotiation with children and with carers and professionals who act as advocates for the child (Oliver, Knight, \& Chandappa, 2006).

Meanwhile some academics have problematised the notions of "vunerability" and "hard to reach" as it can lead to group identities becoming homogenised as a negative social category and children being silenced when constrained by adult surveillance (Valentine, Butler, \& Skelton, 2001). As mentioned in the introduction, looked after children are a diverse group and whilst these children have faced and will face challenging life circumstances, a number of scholars have provided a more nuanced picture that emphasises children's resilience and agency (Mannay et al., 2017), and experiences of consistency of care and placement in safe and secure environments (Sebba et al., 2015).

More recent approaches to research with children also challenge the objectification of children as lacking capacity and insight and are designed to be respectful of children's agency as social actors in their own right and experts in their everyday worlds (Einarsdóttir, 2007). This epistemological view of childhood has a number of implications for research conduct as it recognises children as competent research participants, knowledgeable about their own experiences, and with specific communication skills that researchers can draw upon.

\section{Informed Consent}

The views of looked after children were vital in this study and the researchers were heedful of Clark and Moss (2011), who argued that whilst listening is an expression of rights it is also part and parcel of ethical practice. Drawing on Alderson's (2012) rights-respecting research agenda a 
number of ethical principles were put into practice. This has repercussions for our research and our approach to informed consent which, according to Tisdall, Davis, and Gallagher (2009), involves the children understanding the realities of the research, who is undertaking and financing it, and its hoped-for benefits to other children. Given our understanding of all this, we explained to the children the nature and purpose of the research, and how the information will be used and by whom. They were given opportunities to discuss any concerns and encouraged to ask questions prior to any involvement in the research. They were also assured that the information would remain confidential and that it was not possible for people unconnected with the research to identify them. Pseudonyms were assigned to both children and carers to maintain confidentiality.

To ensure all the children understood the aims and processes of the study, the participants were provided with spoken information and an information leaflet designed to use accessible language that enabled the children to comprehend what the research involved. It was also made explicit that they were under no obligation to participate. As part of the wider study differentiated consent forms were produced for the carers and key professionals. The children were reminded that consent was renegotiable and that they had the right to withdraw from the process at any stage without any implications for themselves. The researchers remained vigilant about any anxiety or embarrassment the children displayed, using what Skånfors (2009) referred to as an "ethical radar", which alerts the researcher to body language cues and signs of resistance even when children do not express their feelings verbally. Attention was also paid to minimising possible coercion from carers and other adults.

Several local authorities in Scotland had already agreed to take part in the Letterbox pilot project so initial contact was made by phone to social work managers in two local authorities in the west of Scotland to discuss the research design. Separate local authority ethics application forms were completed by the researchers and submitted with additional research documentation to the two social work services. As the looked after children participating in the project were under 12 years of age, social services also sought consent from the children's birth parents or the adult who held parental rights and responsibilities for the child.

\section{Research Design}

This research draws on a range of data sources rich in context to offer a credible, in-depth exploration of children's views and opinions as a result of participating in the Letterbox Club. The data collection process lasted 6 months and contained three distinct but interrelated phases to allow the researchers to establish and maintain a respectful relationship with the children and build on learning gained during each stage of the project.

\section{Phase 1}

The first consultation with the children was at a location organised by the social services representatives. The setting was familiar to the children, which supported engagement, and was an environment in which the participants felt comfortable and relaxed, and had a sense of control over 
International Journal of Child, Youth and Family Studies (2017) 8(3-4): 26-58

the situation. It was decided that the home would not be used to avoid intruding into children's private spaces. The children were accompanied at all times by one or both of their carers, and their key social worker.

Professionals from social services played a key role in the selection of participants as care was taken about the choice of children to avoid risk of harm. The sample size was determined by social services based on the willingness of children and carers to participate in the research and the practicalities of accompanying the families to meetings. As such, purposive sampling was employed to yield relevant and information-rich cases related to the phenomena of interest (Palys, 2008), whilst judgements were made by social workers to guarantee a balance of age, gender, and looked after circumstances.

Three separate meetings were held after school with a total of eight families and 11 children. This arrangement was for geographical reasons but in hindsight the size of the group was large enough for the children to feel part of a collective and supportive project but small enough to allow an "intimacy between strangers" (Alderson \& Morrow, 2004).

Profile questionnaires were completed by the children and their carer(s) together and were designed to gain background information to frame the case studies (see Appendix 1). The questionnaires included a broad range of literacy-related topics including the children's favourite books and authors, details of reading practices and routines in the home, and library visits, as well as their expectations of the Letterbox Club. The profile questionnaires were used as a conversation tool and an opportunity to build a rapport with the children and their carers to support the next two phases of the research process. The intention here was to capture the children's lived experiences with literacy as the project commenced and not to establish a baseline for quantitative data comparison as pre- and post-intervention reading assessment tools have proved problematic and unreliable in past evaluations of Letterbox Club initiatives (Winter et al., 2011). For more details of the data captured from the questionnaires see Hancock and Leslie (2014).

\section{Phase 2}

During the second phase data was gathered from evaluation sheets included in each of the six parcels (examples can be seen in the Findings section). For further information on the books included with the parcels, see Appendix 2. Children were asked to indicate their views about the resources using a 4-point smiley face scale. Several scholars (Punch, 2002; Clark \& Statham, 2005) have suggested using a blend of both "adult" and "child-friendly" data-gathering techniques in order not to be patronising to children. Therefore, space for written comments was also available and the children were encouraged to add their own opinions about the books. This phase involved minimal intrusion in the children's lives and gave them the opportunity to respond at a time that was convenient for them. These open-ended comments also ensured that the children felt a sense of ownership over their contribution to the data and alleviated any apprehension about articulating negative aspects of the books. The written comments were used as a stimulus for conversations with the children during the final phase of the project. Sensitivity was shown about any anxiety 
International Journal of Child, Youth and Family Studies (2017) 8(3-4): 26-58

the children evinced about their own confidence and competence with literacy. For some children their carers acted as a scribe; however, one child took the initiative and scribed for another looked after child in the family.

\section{Phase 3}

The third phase consisted of tape-recorded conversations with eight children, from five families. This sample became naturally self-selecting as challenging family circumstances led to a number of children being unable to attend the meetings. In this way the study's findings reached data saturation as the researchers were restricted to the number of children who had participated in all three stages of the research, but it was felt that sufficient data would be generated to replicate the study (Fusch \& Ness, 2015).

The imbalance of power between the researcher posing the questions and the participant responding to them is particularly pronounced during adult-child interactions and thus it may lead children to answer in ways that they think researchers are expecting. These individual sessions were therefore relatively informal and conversational in style using the children's evaluation forms as a stimulus for open-ended questions. The children were encouraged to expand on ideas expressed on their written evaluation sheets and were given the opportunity to articulate their perceptions in their own words. The parcels were also on hand so that the children could follow their interests during the conversations and use the books to support their thinking. All the final interviews were recorded, with the permission of the participants, and fully transcribed.

Some children preferred to use drawing to communicate their experiences of receiving the parcels. This alternative format allowed the children to express a range of emotions and understandings using their visual memory, without the constraints of oral language (Merriman \& Guerin, 2006; Einarsdóttir, Dockett, \& Perry, 2009). That said, assumptions were not made that all children would prefer to use this medium of communication and care was taken to ensure pictures were not falsely interpreted (Harden, Scott, Backett-Milburn, \& Jackson, 2000).

The approach to data analysis was inductive in nature, allowing ideas and themes to emerge from the content of the various sources of data outlined above (Guest, Macqueen, \& Namey, 2011). The procedure involved both of the researchers working independently at first, reading and rereading the data thoroughly to become familiar with the content and composing descriptive comments. This was followed by cross-checking individual interpretations and coding collaboratively to validate the themes emerging from each family. Finally, the process was repeated case by case and patterns were identified to illuminate the differences and subtle similarities among the children. These co-constructed conversations and reflections contributed to revision and recoding as interpretations were shared, examined, and debated. Through this critical and reflexive reading of the data, a number of strong themes became evident including reading practices, individual responses to books, and children's agency as independent learners. The data were verified with the key social workers throughout the process to provide some measure of 
reliability. Unfortunately, respondent validation was not possible because of access restrictions to the children and their carers from social services.

A difficulty for any researcher using this type of qualitative analysis is the transfer of naturally occurring data to research data without investigator distortion, a hazard when interpreting the lives of "others". To avoid this potential limitation, the researchers attempted to "bracket" subjective experience and suspend judgment about the natural world while focusing on the analysis of the children's lived experience with reading (Tufford \& Newman, 2012). At the same time, an emphasis was placed on the children's personal narratives as a resource for providing them with a voice for expressing the experiences of looked after children.

Table 1 Details of Looked After Children and Carers

\begin{tabular}{llrl}
\hline Name & Parcel & Age & Care Arrangement \\
\hline Caitlin & Red & 10 & Foster care with Tom and Grace \\
Jack & Blue & 7 & \\
Rachel & Red & 10 & Foster care with Alison \\
Kyle & Blue & 7 & \\
Michael & Blue & 8 & Kinship care with grandmother \\
Ryan & Blue & 9 & Foster care with Helen and Dave \\
Lauren & Blue & 8 & Kinship care with Aunt \\
Emily & Blue & 7 & \\
\hline
\end{tabular}

\section{Findings}

\section{Reading Practices}

Even before the project began a number of the children reported that they were avid readers and enjoyed reading independently. The children made choices about where and when they read and had their own established reading routines and book preferences (including repeated reading of books). Caitlin demonstrated a passion for reading and confided that she buys books from charity shops and reads constantly even "in the middle of getting ready" in the morning. Her favourite author is Jacqueline Wilson and recently her carer bought her the complete set of this author's books, which Caitlin thought "was amazing". Like Caitlin, Rachel also describes herself as "a really good reader". She reads every day and reading makes her feel "really happy". For Rachel going to the library is an "exciting" experience and she likes to read different types of books, including "funny ones, some that have a wee scary bit in them, happy ones, adventure ones, and princess ones". She sometimes reads the same book "over and over again". She particularly enjoys the Famous Five and Malory Towers series and books by David Walliams. Another girl, Lauren, also reads regularly on her own, particularly what she calls "books with lots of chapters" such as the Horrid Henry series. 
International Journal of Child, Youth and Family Studies (2017) 8(3-4): 26-58

Predictably not every child was an able reader but they looked for different ways to engage with texts. Michael revealed that he does not like reading "because it's hard" and prefers "looking at comics" and "just going out and playing". At bedtime Michael usually watches DVDs, although he did mention that occasionally he would take one of the books from the parcels to bed. He explained that he was not able to read the book independently:

I just look at the pictures 'cause I am not with my Gran. My Gran can't help me so I just read words that I can in my bed, then when it's time to go to sleep I go to sleep.

Emily, who repeated one year of schooling because of her additional support needs was aware of her difficulties with reading, claiming "I just like looking at the pictures because I can't read" (Figure 1). Emily also found O'Connell's (2009) Ancient Egypt Sticker Book "hard to read", but was delighted with the stickers. She was able to locate the correct place for each sticker by looking closely at the shape of each object and matching the objects to the blank spaces on the pages. Talking about this book she said, "I loved that one by the way. I founded them all without reading".

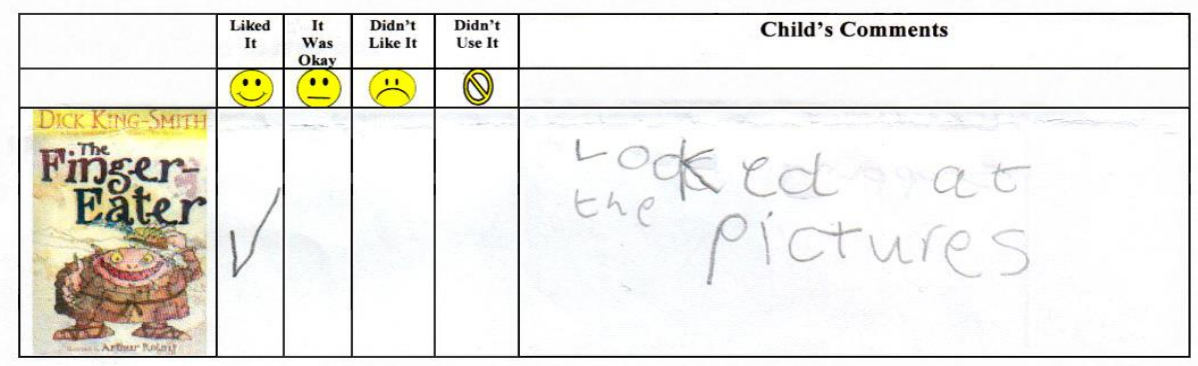

Figure 1. Emily's comment sheet.

Emily and Michael's perceptions of themselves as readers echoes Levy's (2011) findings where children viewed reading to be only about decoding words and those who could not decode print did not see themselves as readers. In contrast, authors like O'Neil (2011) recognise the importance of picture-reading skills in developing children as "readers", as there is much to be understood and inferred from a picture.

A number of the children talked about enjoying reading in bed (Figure 2), taking the books on extended family short breaks, and listening to the story CDs from the parcels in the car or at bedtime. Kyle particularly liked Walker and Sharkey's (2006) Jack and The Beanstalk CD and Emily enjoyed Simon's (2010) Horrid Henry Rocks CD (Figure 3). Some authors such as Dymoke and Griffiths (2010) have noted some limitations of CDs as they only offer abridged versions of the original book making it impossible to follow the text and listen to the story simultaneously. Furthermore, they argue that audiobooks are considered a poor substitute for an adult and child bonding by reading together. 
International Journal of Child, Youth and Family Studies (2017) 8(3-4): 26-58

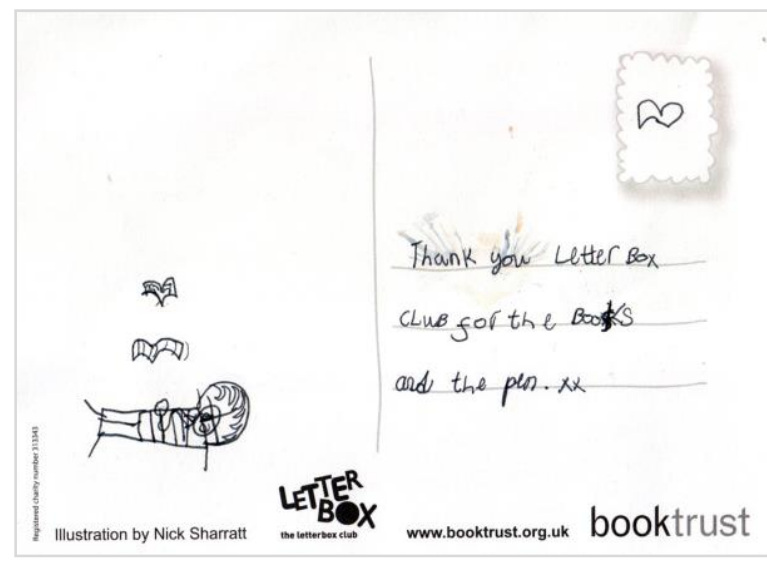

Figure 2. Ryan's drawing: "That's me reading in bed".

A counterargument is that listening to CDs can allow children to enjoy texts that are in advance of their reading level and expand their vocabularies. Furthermore, hearing a book read aloud by a gifted storyteller can add drama, intrigue, and humour to a story and introduce the listener to a variety of language styles. Kirkpatrick (2012) also believes in the therapeutic nature of listening to the spoken word. This was important for Ryan who had difficulty sleeping, due in part to the instability of frequent care moves. He said he enjoyed listening to Walker and Sharkey's (2006) Jack and the Beanstalk and Simon's (2010) Horrid Henry Rocks CDs by himself after his two bedtime stories.

Through the children's conversations there were numerous insights into the social interactions that surround reading and sharing books. These interactions included Ryan and his dad, Dave, spending time together reading the books from the parcel and cycling together to the library; Rachel's family "taking turns" reading some of the books from the parcel and "having fun together"; and Lauren's family with "all 3 sitting round the kitchen table reading”.

Rachel and Kyle shared the contents of their Blue and Red parcels, "swapping books", "looking at each other's things", and reading the books together. As with Rachel's home, there were other families with more than one looked after child. This provided opportunities for shared reading with more experienced older readers in a process of guided participation (Rugoff, 1990). Caitlin explained how she would read Jack's books to him as well as reading her own books to him. Furthermore, she scribed his views about the materials on the comment forms. Lauren also played a significant role in scaffolding her sister Emily's reading by "sounding out" the words rather than giving her the words.

This sharing of books also went beyond the immediate family with Emily taking the CD and book to a friend's house (Figure 3); Michael taking the books to his Auntie's house where she read "a wee bit" to him; and Rachel sharing with friends at the Girl Guides. Many of the children also took the books to school to show their teachers and classmates as described later. 
International Journal of Child, Youth and Family Studies (2017) 8(3-4): 26-58

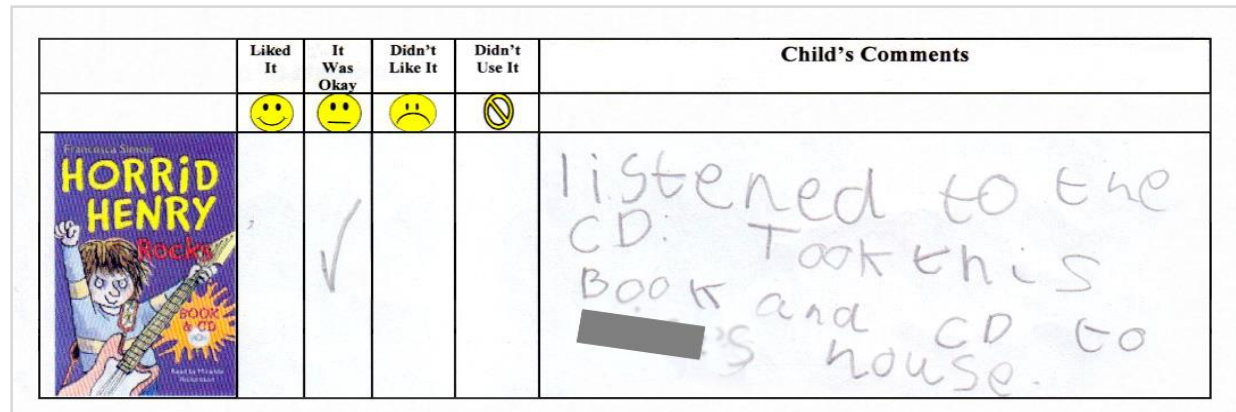

Figure 3. Emily's comment sheet.

Research indicates that the type of social interactions cited above are not only important for children's language and literacy development but these shared practices are also accompanied by encouragement and feelings of friendship - all of which support children's self-esteem and relationship building (Hancock \& Leslie, 2011).

\section{Individual Responses to Books}

The children's responses to the books were gathered from the written comments and tick boxes on the evaluation sheets and later validated by conversations with the children. Descriptions included "love it", "great", "liked it", and "really interesting" (Figure 4).

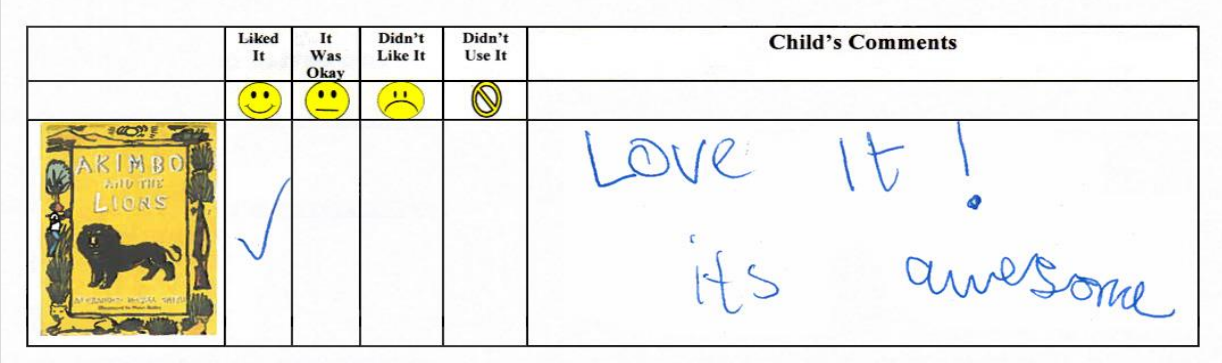

Figure 4. Caitlin's comment sheet.

Scribing for Jack had encouraged Caitlin to listen carefully to him about what he thought about the books, and she took the initiative to add an additional column herself to the comment sheet with the category "Loved It" (not shown). Several of the children also commented on specific storylines or characters (Figures 5 and 6). 
International Journal of Child, Youth and Family Studies (2017) 8(3-4): 26-58

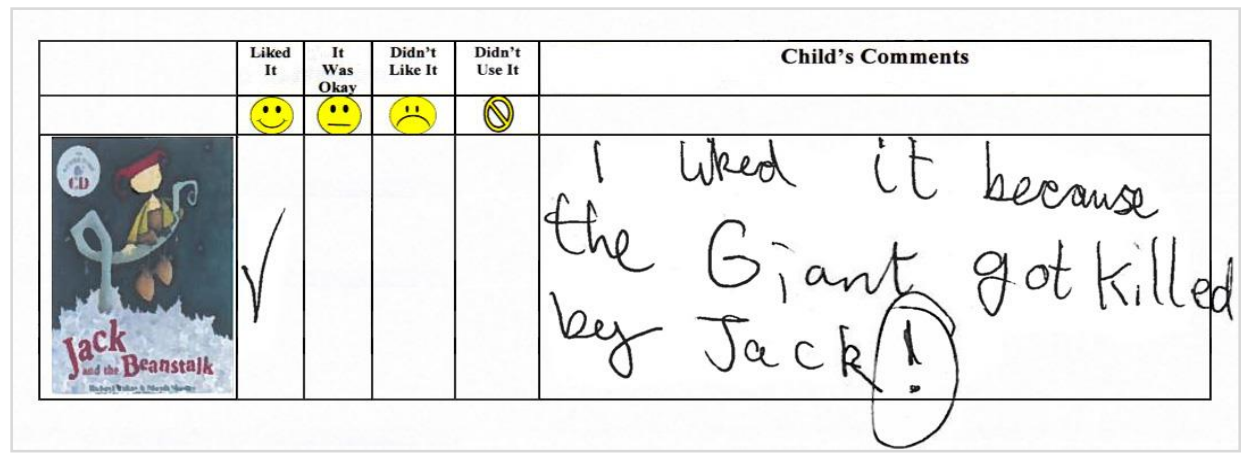

Figure 5. Jack's comment sheet scribed by Caitlin.

\begin{tabular}{|c|c|c|c|c|c|}
\hline & $\begin{array}{c}\text { Liked } \\
\text { It }\end{array}$ & $\begin{array}{c}\text { It } \\
\text { Was }\end{array}$ & $\begin{array}{l}\begin{array}{l}\text { Didn't } \\
\text { Like It }\end{array} \\
\end{array}$ & $\begin{array}{c}\text { Didn't } \\
\text { Use It }\end{array}$ & Child's Comments \\
\hline & 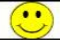 & $(\ddot{-}$ & $\ddot{\circ}$ & (Q) & \\
\hline 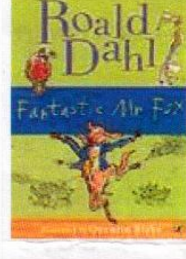 & $\checkmark$ & & & & $\begin{array}{l}\text { This was very funny. Some } \\
\text { parts were a bit sad too. } \\
\text { My teacher ukes this book. } \\
\text { I like the part about the } \\
\text { farmo digging up the } \\
\text { tree roots. }\end{array}$ \\
\hline
\end{tabular}

Figure 6. Rachel's comment sheet.

Books associated with popular culture were well received by the children. In particular, the Harry Potter film and television programmes (The Deadly 60 and Horrid Henry) were mentioned in the interviews (Figure 7). Echoing the study carried out by Marsh et al. (2005), the children consciously related the books to the television programmes, drawing on the language experienced with the moving image text to develop their own narratives (Scottish Screen, 2009).

\begin{tabular}{|c|c|c|c|c|c|}
\hline & $\begin{array}{c}\text { Liked } \\
\text { It }\end{array}$ & \begin{tabular}{|c|} 
It \\
Was \\
Okay \\
\end{tabular} & $\begin{array}{l}\begin{array}{l}\text { Didn't } \\
\text { Like It }\end{array} \\
\end{array}$ & $\begin{array}{l}\text { Didn't } \\
\text { Use It } \\
\end{array}$ & Child's Comments \\
\hline & 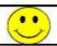 & $\ddot{-}$ & $\ddot{2}$ & (1) & \\
\hline 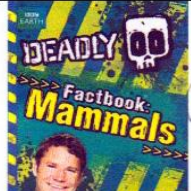 & $\mathrm{C}^{\circ}$ & & & & $\begin{array}{l}\text { This book is very intoresting } \\
\text { becavose it tell you all } \\
\text { abowit animab. g watch this } \\
\text { on T.V. }\end{array}$ \\
\hline
\end{tabular}

Figure 7. Ryan's comment sheet scribed by his dad.

Interestingly, Michael, who had referred to himself as "poor reader", was keen to talk about the knowledge he had gained from the Deadly 60 presenter regarding what action to take if a poisonous snake bites you: 
International Journal of Child, Youth and Family Studies (2017) 8(3-4): 26-58

And he shows you what the animals are, poison and all that, and what they can do. And this snake bit a guy and you have to start putting more blood into you and keep on doing it until you get normal blood again. If it's a poison snake you have to keep on — there is this big jag [medical injection] machine you take with you ... you have to keep on jagging yourself till you get all the poison blood into that jag and then it puts normal blood into you.

Research indicates that, for children, engaging with popular culture can be very motivating and encourage the habit of reading (Marsh \& Millard, 2000). One implication for the Letterbox Club is that fashions wax and wane and the choice of books needs to be kept contemporary.

The parcels contained a range of non-fiction books to cater for varied genre tastes, such as Backshall's (2012) Deadly Factbook: Mammals, described by Ryan in Figure 7. There is a lack of research conducted with children comparing reading non-fiction with fiction, despite that fact that their language and knowledge demands differ. Some studies, however, indicate that children are adept at reading informational texts but they require practice to become acquainted with the genre (Wray \& Lewis, 1997). Ryan clearly enjoyed the non-fiction texts in the parcels and liked extracting information from books. He explained:

I like information. Kind of like ... if someone walked over to me and was interested in Vikings and they said, “What would Vikings eat?" Well I would, if I didn’t know that ... I don't know, but if I had information (I do know what they ate), but if I had information I would be able to say fish and porridge, oatcakes.

Michael liked Dorling Kindersley's (2006) Human Body (Eye Wonder) and he rated it as "good" because "it learns you how to take care of your bones and all that". Emily has a similar view (Figure 8).

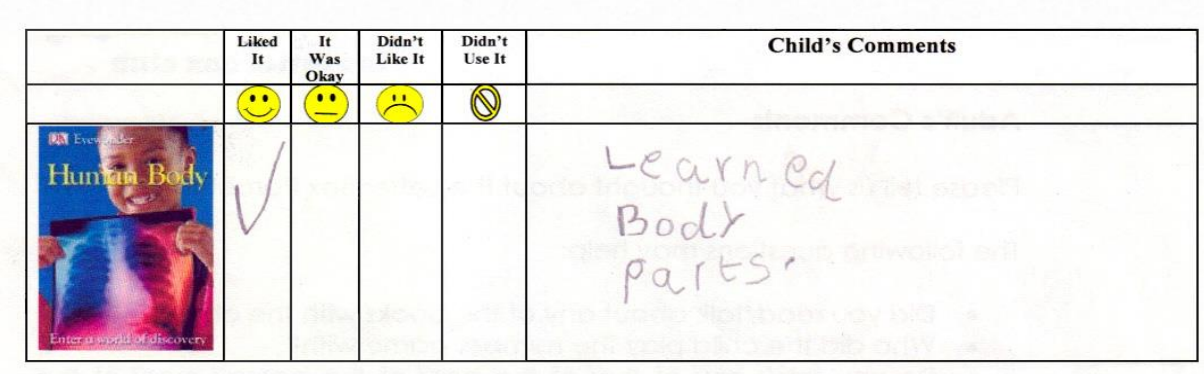

Figure 8. Emily's comment sheet.

Caitlin described opening one of the parcels (Figure 9):

My wee brother was like "open it, open it" and he was urging me, so I opened it, and then I saw owls, and I really, really like owls, 'cause I like the way that they 
move and the way that they fly ... I like owls, so it was quite good to have an owl book. So I read it all in like two minutes.

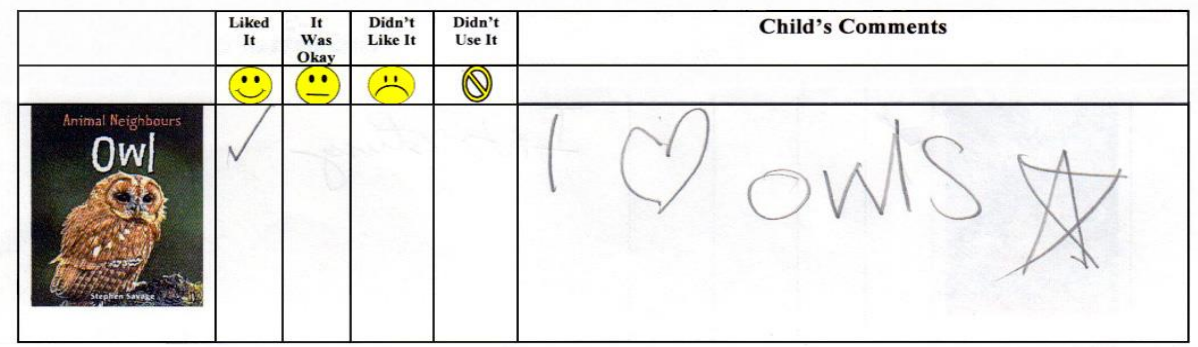

Figure 9. Caitlin's comment sheet.

Some of the books were based on traditional fairy tales, allowing the children to read familiar stories. Both Emily and Lauren said they loved Collodi's (2004) Pinocchio and described how they had seen the story performed in the theatre. Ryan was excited to discover Pinocchio in the parcel as he said he was going to see it at a pantomime at Christmas (Figure 10). For Emily, Walker and Sharkey's (2006) Jack and the Beanstalk was a favourite book (Figure 11) and she also spoke about Don's (2012) Little Red Riding Hood saying, "I know this story very well”. Fairy tales can teach critical thinking skills, develop a child's imagination, and build emotional resilience (Kirkpatrick, 2012).

\begin{tabular}{|c|c|c|c|c|c|}
\hline & $\begin{array}{c}\text { Liked } \\
\text { It }\end{array}$ & $\begin{array}{c}\text { It } \\
\text { Was }\end{array}$ & $\begin{array}{l}\text { Didn't } \\
\text { Like It }\end{array}$ & $\begin{array}{l}\text { Didn't } \\
\text { Use It }\end{array}$ & Child's Comments \\
\hline & 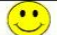 & () & $\ddot{2}$ & (Q) & \\
\hline 8 & & & & & $\begin{array}{l}\text { I WKED MY DAD READINZ } \\
\text { ME THIS STOKY. BECAUSE I AM } \\
\text { GOING TO SEE THE PAMTOMINE } \\
\text { AT CHRISTMAS. } \\
\text { I CAN WATCH FOR PINOCCHIO'S } \\
\text { NOSE GETTINR BIGGCR. }\end{array}$ \\
\hline
\end{tabular}

Figure 10. Ryan's comment sheet scribed by his carer. 
International Journal of Child, Youth and Family Studies (2017) 8(3-4): 26-58

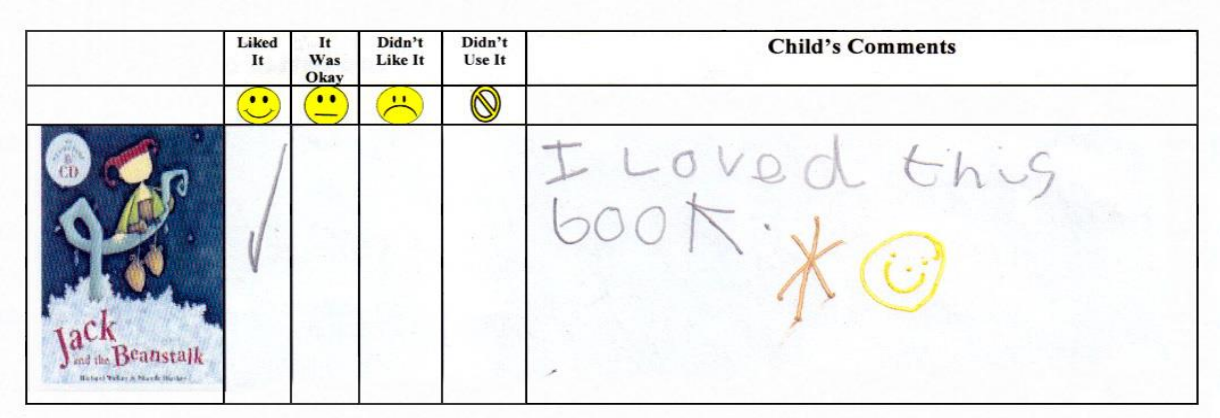

Figure 11. Emily's comment sheet.

For some children, books by particular authors, or books that were part of a collection, acted as a "hook" to read more books by the same author. Ryan was thrilled to get Ross' (2010) Horrid Henry because he described himself as a "fan" and owned other titles in the series. Lauren loved Roald Dahl and she had already read his George's Marvellous Medicine (1981) and was delighted to discover his The Enormous Crocodile (1978) in one of the parcels. She confessed that she was asking Santa for the "whole selection of Roald Dahl books". Both Caitlin and Rachel enjoyed Rowling's (1997) Harry Potter and the Sorcerer's Stone, stating that it was the first book they had read in the series. Caitlin was keen to read more of them whereas Rachel declared that she would save up all her pocket money to buy them. Rachel commented it was "really adventurous". Rachel said that she had seen the films, but now felt that she preferred the books as "they tell a little bit more".

The children also offered feedback about not liking a book. These comments included "babyish" (Figure 12), "boring", and "hard to read" (Figures 12 and 13).

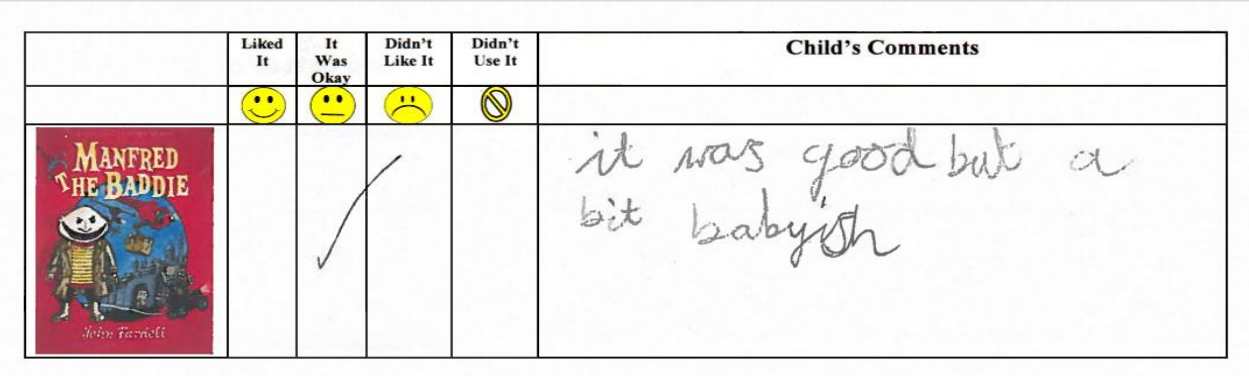

Figure 12. Caitlin's comment sheet. 
International Journal of Child, Youth and Family Studies (2017) 8(3-4): 26-58

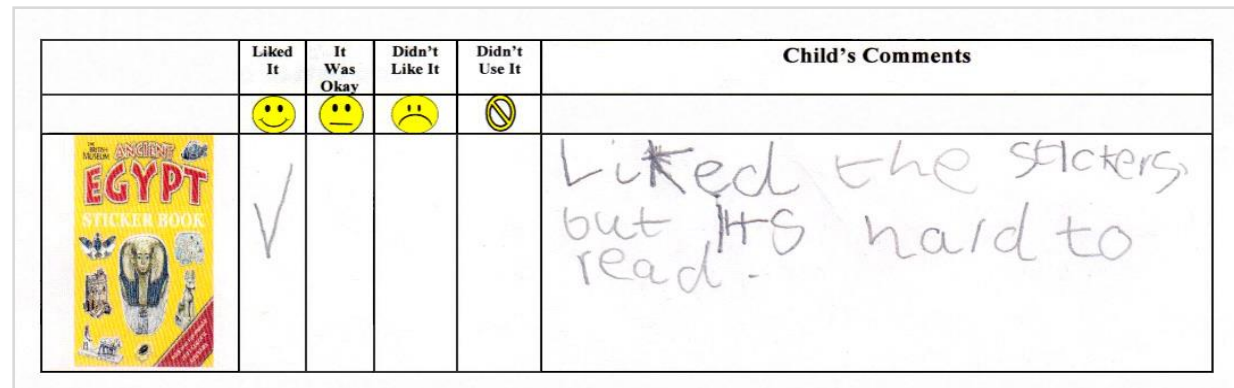

Figure 13. Emily's comment sheet.

For some children with additional support needs (such as Michael and Emily), some of the books were not appropriate for their stage of reading development. However, when selecting books to read from the parcels Michael was able to put into practice some of the strategies he had been taught at school to make an informed choice. Talking about King-Smith's (2012) The Finger Eater he justified why it had not appealed to him:

Didn't really read it. Nuh, didn't like it. Because it didn't look good from the outside and then when I looked at the pictures inside and then I read the thing on the back, see the blurb, read that, it didn't sound that good. I didn't like it.

The children liked being asked for their opinions about the contents of the parcels and, in the main, were keen to offer their suggestions about how the parcels could be improved. For example, Ryan had ideas about what could be included in other parcels at different stages. He thought the Primary Six children would benefit from "a danger book" that would prevent "very stupid people touching electricity" and for Primary Five children a history book about kings and queens. Meanwhile, Rachel thought that if she were to make up the parcels she would include more non-fiction books.

Caitlin's involvement in the Letterbox Club seems to have prompted her to consider the needs of others. She talked a lot about the educational value of the parcels, not just in terms of her own development, but also that of other children who were not good readers. For example, she highlighted the fact that Bradman's (2008) The Two Jacks was described as "a dyslexia friendly book" and thought it would be good for some of the children in her class.

One of the things that Caitlin really liked about being in the Letterbox Club was that children were asked to give their opinions about the books and that their views would be respected. She explained:

Well, I think it's just because you get your say in it. I mean if you like the books you can say, "I like the books", and if you don't like the books you can just say that you didn't like them and it doesn't really matter if you're a good reader or not, it just depends on what your opinion is. Yeah, I like the way that they do these smiley faces, like that, and then the comment 'cause you can just write what you feel, and 
International Journal of Child, Youth and Family Studies (2017) 8(3-4): 26-58

... you can just tell, and just share your feelings and it's good to know that nobody will shout at you and nobody will moan at you as well.

\section{Children's Agency as Independent Learners}

Having agency means children being able to make decisions and choices that influence events and which have an impact on their own lives (Waller \& Bitou, 2011). The children's opinions cited above and the actions they took during daily negotiations about how, when, where, and with whom they read, and their genre choices, are all illustrations of children developing a sense of agency. In this way the children's identities as independent readers were reinforced. The following examples show children using the contents of the parcels to make autonomous choices and take greater ownership over their own learning and schoolwork.

Michael particularly liked O'Connell's (2009) Ancient Egypt Sticker Book because Egypt was his current class topic. However, his Gran told him that she did not want any of the books "to get damaged" by taking them to school. As Michael does not have a computer in the house, he took the initiative and decided to go to his Auntie's house to ask her to use her computer to print "stuff about Egypt". He took the material that he had downloaded from the internet to show his teacher. Relating the story to the researcher, it was apparent that Michael had a sense of pride in his endeavour and a feeling of control over his own learning. This was particularly important for a child who was described as "always getting into trouble at school" and "on a behaviour report card".

After receiving some of the books, Kyle decided to use an exercise book in one of the parcels to record all the books that he had read since he was a baby. He asked his carer the name of his first book and his first reading book at school. He then used his recollections to compile a written list of books (Figure 14).

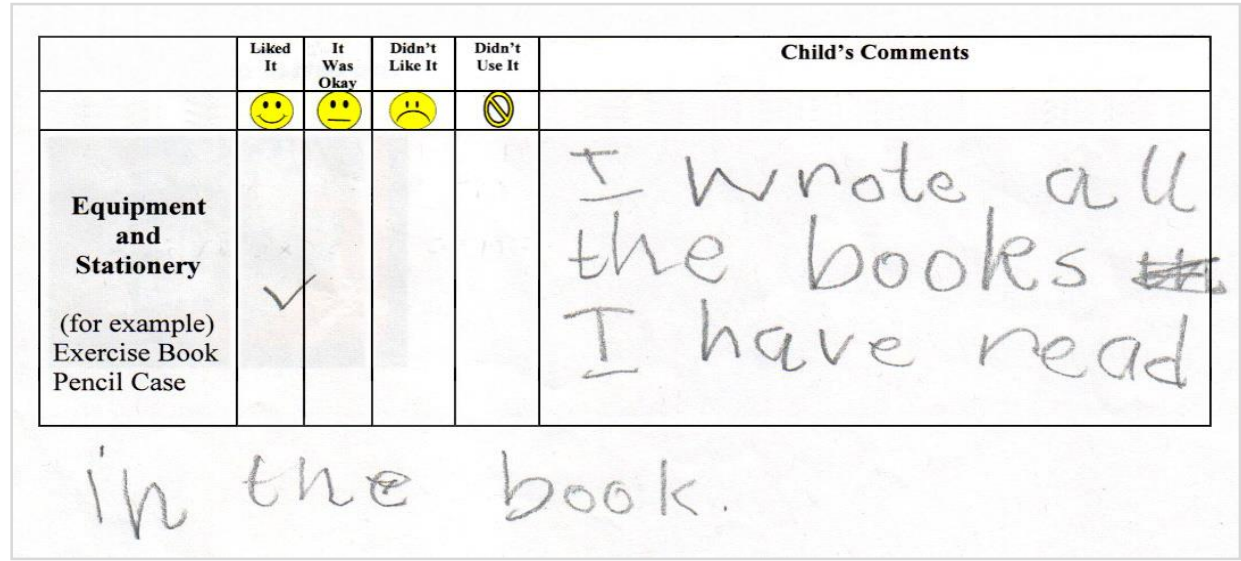

Figure 14. Kyle's comment sheet. 
International Journal of Child, Youth and Family Studies (2017) 8(3-4): 26-58

Caitlin believed that being a member of the Letterbox Club had been "very good" for her in terms of extending her vocabulary. She described how sometimes she came across words in the books from the parcels that she was "not sure of" and she would ask her carers to explain the meaning. She continued, "They explain it and then I explain it back to them, and then I get a sort of idea in my head". On other occasions, she divulged that she tried to do it herself and she "didn't go straight away" to ask her carers; rather she tried "to figure it out using the sentence and the picture".

Noon's (2012) Story of the Titanic stood out for Rachel as it coincided with the topic she was studying at school (Figure 15). She said: "When I opened the parcel I thought WOW!" She was excited as she had to make a model of the Titanic and she used the book to help her. Rachel chose to take the book to show her teacher. This proved to be a positive experience as the teacher had the same book, and she asked Rachel to help her read the book to the whole class. Rachel told this story with a feeling of pleasure and added that the teacher had asked her if she could leave her book at school for a few days so that it could be shared with all the children.

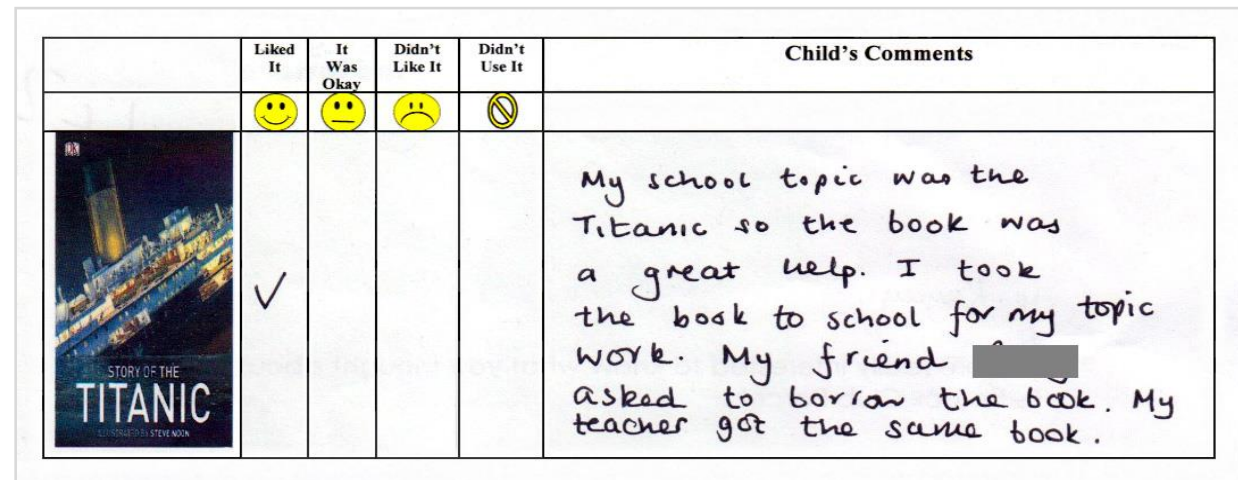

Figure 15. Rachel's comment sheet.

\section{Discussion and Conclusion}

Although the discourse of "consulting with children" has gained prominence in political and educational forums of late, children frequently "continue to find their voices silenced, suppressed, or ignored ... and even if they are consulted, their ideas may be dismissed" (James, 2007, p. 261). Children are the best judges of what they would like to read and the findings demonstrate that many of the children valued being given the opportunity to express their opinions about the books - they felt that their views mattered. However, it is not just about listening to children but also taking them seriously, turning their ideas into reality, and involving them directly in any future selection of books to be included in the parcels.

Promoting children's agency has been identified as fundamental to children's learning, development, and wellbeing (Corsaro, 2005). Conditions promoting agency are particularly important for looked after children and how they manage their sense of identity, not just in terms 
of their education but also in their daily interactions and relationships at home and school. The findings reveal children having multifarious reading proficiencies, reading habits, reading routines, and author and book genre preferences. This nuanced picture of children's experiences with reading sheds light on the heterogeneous nature of looked after children and their family contexts. Looked after children's disadvantaged status should not be ignored (Berridge, 2007). This study demonstrates children responding to such a positioning in diverse and strategic ways, such as: making choices about where and when they read and with whom; expressing opinions about books (including likes and critiques); and using the contents of the parcels to take action and gain greater ownership over their own learning and schoolwork.

The idea that children can be vulnerable, as they start out from different power positions compared to adults (Leonard, 2015), and yet can exercise agency at the same time depending on what they are faced with, requires further scrutiny (Bluebond-Langner \& Korbin, 2007). Bordonaru and Payne (2012) have referred to this phenomenon as "ambiguous agency". Hancock, Hancock, and Leslie (2014) have argued that interpretations of agency and how it is achieved continue to be wide-ranging and children's capacity for agency should be perceived as a varying and moveable construct, set within the context of daily negotiations and relationships with others. Tisdall and Punch (2012) stated that children's agency should be a contested construct, rather than one that is taken for granted or assumed to be inherently positive and desired by all children. For example, Michael's social worker informed the researchers that the final parcel remained unopened in the home and a number of children chose not to complete or return the evaluation forms. The reasons behind this are complex and speculative in nature but it could be argued that the children were asserting their authority and choosing not to participate. According to Tisdall and Punch (2012, p. 259), focusing on children's agency is no longer enough and greater emphasis is needed on the "intricacies, complexities, tensions, ambiguities and ambivalences" of children's lives. We believe taking this stance alongside a perception of agency as "potential" (Ratner, 2000), and fluctuating rather than static, will assist scholars, policymakers, and practitioners to engage more critically with studies involving looked after children in the future.

With the move to problematising agency have come reassessments of what constitutes authentic, inclusive, and ethical research with children who are asked to provide insights into their own lives. A number of restraints and pragmatic decisions influenced the conduct of the research outlined in this article, but on reflection there should have been greater involvement of the children at every stage, including designing the questionnaire and the evaluation sheet. How we communicate and share information with the children to allow them to make real choices is complex. Langhout and Thomas (2010) pointed out that the act of consulting with children sounds like a good idea until we hear what they have to say, as children's perspectives may challenge the social order of the researcher as well as institutional or community values and norms. That said, future research with looked after children needs to consider how children can participate in decision-making from the start. This calls for researchers both to be open about the issues and who benefits, and to collaborate with children when developing research tools. Feedback on research 
findings should also be routinely provided to children as part of acknowledging their contribution and seeking their views on dissemination and outputs, as well as gaining their thoughts on withdrawing from the research process.

The Letterbox project has been rolled out across the UK but it remains small scale as it relies on the good will of professionals and financial support from educational authorities in a time of budgetary constraints. The Letterbox Club involves interagency partnerships but there needs to be greater engagement with libraries and schools. This could involve the lending of books and engaging with carers about participating in literacy practices in the home. The project has the potential for replication across international contexts but its impact needs to viewed as an integral component of other measures to raise literacy standards for all children. For example, in Scotland, there have been numerous national initiatives to support children's reading such as the Scottish Government's Play Talk Read campaign and Scottish Book Trust's Bookbug schemes ${ }^{4}$ (Scottish Government, 2015b). How these initiatives are inclusive of, and recognise, looked after children warrants further investigation.

\footnotetext{
${ }^{4}$ Working through locally based partners including libraries, health professionals, early years settings, and primary schools, free packs of books are gifted to all children in Scotland when they are aged around six weeks, eighteen months, three years, and when they start school at five years of age, along with guidance materials for parents and carers. A number of research studies have been commissioned in Scotland to look at the impact of the bookgifting programme, including Berry and McMellon (2008) who reported on the benefits of intervening early and building a foundation of literacy in young children.
} 
International Journal of Child, Youth and Family Studies (2017) 8(3-4): 26-58

\section{References}

Alderson, P. (2012). Rights-respecting research: A commentary on 'The right to be properly researched: Research with children in a messy, real world'. Children's Geographies, 10(2), 233-239. doi:10.1080/14733285.2012.661603

Alderson, P., \& Morrow, V. (2004). Ethics, social research and consulting with children and young people. Ilford, Essex: Barnardo's.

Alvermann, D. E. (2011). Popular culture and literacy practices. In M. L. Kamil, P. D. Pearson, E. B. Moje, \& P. P. Afflerbach (Eds.), Handbook of reading research (Vol. 4, pp. 541-560). New York, NY: Routledge/Taylor \& Francis Group.

Berridge , D. (2007). Theory and explanation in child welfare: Education and looked-after children. Child \& Family Social Work 12(1), 1-10. doi:10.1111/j.1365-2206.2006.00446.x

Berry, H., \& McMellon, C. (2008). 'Special time together': An evaluation of bookstart in South Lanarkshire. Market Harborough, UK: Greenshoots Research and Development.

Bluebond-Langner, M., \& Korbin, J. E. (2007). Challenges and opportunities in the anthropology of childhoods: An introduction to "children, childhoods, and childhood studies". American Anthropologist, 109(2), 241-246. doi:10.1525/aa.2007.109.2.241

Boddy, J., Statham, J., Danielsen, I., Geurts, E., Join-Lambert, H., \& Euillet, S. (2014). Beyond contact? Policy approaches to work with families of looked after children in four European countries. Children \& Society 28, 152-161. doi:10.1111/chso.12068

Bordonaro L., \& Payne, R. (2012). Ambiguous agency: Critical perspectives on social interventions with children and youth in Africa. Children's Geographies, 10(4), 365-372. doi: $10.1080 / 14733285.2012 .726065$

Brodie, I. (2005). Education of children in public care (Highlight no. 218). London,UK: National Children's Bureau.

Cairns, K., \& Stanway, C. (2004). Learn the child. Helping looked after children to learn: A good practice guide for social workers, carers and teachers. London, UK: British Association for Adoption \& Fostering.

Cameron, C., Connelly, G., \& Jackson, S. (2015). Educating children and young people in care: Learning placements and caring schools. London, UK: Jessica Kingsley.

Centre for Excellence for Looked After Children in Scotland. (2016). Improving the learning journey of looked after children. Glasgow, Scotland: Author. 
International Journal of Child, Youth and Family Studies (2017) 8(3-4): 26-58

Chambers, B., Cheung, A., Slavin, R., Smith, D., \& Laurenzano, M. (2010). Effective early childhood education programs: Best evidence synthesis. Reading, UK: CfBT Education Trust

City of Edinburgh Council. (2010). Reading Champion report 2005-2010. Retrieved from http://www.library.ie/youngpeople/wpcontent/uploads/ReadingChampionReportFinal15Sept2010(1).pdf

Clark, C. (2014). Children's and young people's reading in 2014: Findings from the 2014 National Literacy Trust's annual survey. London, UK: National Literacy Trust.

Clark, A., \& Moss, P. (2011). Listening to young children. The mosaic approach. London, UK: National Children's Bureau.

Clark, A., \& Statham, J. (2005). Listening to young children: Experts in their own lives. Adoption and Fostering, 29(1), 45-56. doi:10.1177/030857590502900106

Cole, J. (2011). A research review: The importance of families and the home environment. London, UK: National Literacy Trust.

Corsaro, W. A. (2005). Collective action and agency in young children's peer cultures. In J. Qvortup (Ed.), Studies in modern childhood: Society, agency, culture. Basingstoke, UK: Macmillan.

Cundy, J., \& Duffy, M. (2009). Looked after children with additional support needs: A scoping study. Glasgow, Scotland: Barnardo’s.

Driscoll, J. (2013). Supporting the educational transitions of looked after children at Key Stage 4: The role of virtual schools and designated teachers. Journal of Children's Services, 8(2), 110-122. doi:10.1108/JCS-09-2012-0006

Dymoke, S., \& Griffiths, R. (2010). The Letterbox Club: The impact on looked-after children and their carers of a national project aimed at raising achievements in literacy for children aged 7 to 11 in foster care. Journal of Research in Special Educational Needs, 10(1), 52-60. doi: 10.1111/j.1471-3802.2009.01143.x

Einarsdóttir, J. (2007). Research with children: Methodological and ethical challenges. European Early Childhood Education Research Journal, 15(2), 197-211.

Einarsdóttir, J., Dockett, S., \& Perry, B. (2009). Making meaning: Children's perspectives expressed through drawings. Early Childhood Development and Care, 179(2), 217-232. doi:10.1080/03004430802666999

Finn, M. (2008). Evaluation of reading rich. Edinburgh, Scotland: Scottish Government Social Research. Retrieved from http://www.scotland.gov.uk/Resource/Doc/231567/0063158.pdf 
International Journal of Child, Youth and Family Studies (2017) 8(3-4): 26-58

Foy, J. G., \& Mann, V. (2003). Home literacy environment and phonological awareness in preschool children: Differential effects for rhyme and phoneme awareness. Applied Psycholinguistics, 24(1), 59-88. doi:10.1017/S0142716403000043

Fry, D. (1985). Children talk about books: Seeing themselves as readers. Milton Keynes, UK: Open University Press.

Fusch, P. I., \& Ness, L. R. (2015). Are we there yet? Data saturation in qualitative research. The Qualitative Report, 20(9), 1408-1416. Retrieved from http://nsuworks.nova.edu/tqr/vol20/iss9/3

Gee, J. (1990). Social linguistics and literacies: Ideology in discourses. London, UK: Falmer Press.

Glazzard, J., \& Palmer, J. (2015). Enriching primary English. Northwich, UK: Critical Publishing.

Griffiths, R., \& Comber, C. (2011). The Letterbox Club in Wales. Evaluation report 2009-2011. Leicester, UK: University of Leicester School of Education.

Griffiths, R., Dymoke, S., and Comber, C. (2009). The Letterbox Club 2007 to 2009: Final evaluation report. Leicester, UK: University of Leicester, School of Education.

Guest, G., Macqueen, K., \& Namey, E. E. (2011). Applied thematic analysis. London, UK: Sage.

Hall, J., Sylva, K., Melhuish, E., Sammons, P., Siraj-Blatchford, I., \& Taggart, B. (2009). The role of pre-school quality in promoting resilience in the cognitive development of young children. Oxford Review of Education, 35, 331-352. doi:10.1080/03054980902934613

Hancock, A. (2008). Attitudes and approaches to literacy in Scottish Chinese families. Language and Education, 20(5), 355-373. doi:10.2167/le641.0

Hancock, A., \& Leslie, M. (2011). Early years writer in residence project evaluation. Edinburgh, Scotland: Scottish Book Trust. Retrieved from http://www.scottishbooktrust.com/files/shared/bookbug/early_years_writer_residency_eval uation_2011.pdf

Hancock, A., \& Leslie, M. (2014) Letterbox Club Scotland: Report to BookTrust. London, UK: BookTrust.

Hancock, A., Hancock, J., \& Leslie, M. (2014). An evaluation of the Letterbox Club pilot in Scotland: Perceptions of children and carers. Paper presented at the 24th European Early Childhood Education Research Association annual conference, Crete, Greece. 
International Journal of Child, Youth and Family Studies (2017) 8(3-4): 26-58

Harden, J., Scott, S., Backett-Milburn, K., \& Jackson, S. (2000). Can't talk, won't talk?: Methodological issues in researching children. Sociological Research Online 5(2), 1-12. doi:10.5153/sro.486

Hayes, D. (2005). Gaining access to data sources in statutory social work agencies: The long and winding road. British Journal of Social Work, 35, 1193-1202. doi:10.1093/bjsw/bch295

Heath, S. B. (1983). Ways with words: Language, life and work in communities and classrooms. Cambridge, UK: Cambridge University Press.

Heptinstall, E. (2000). Research note. Gaining access to looked after children for research purposes: Lessons learned. British Journal of Social Work, 30(6), 867-872. doi:10.1093/bjsw/30.6.867

Her Majesty's Inspectorate of Education. (2008) Count us in: Improving the education of our looked after children. Edinburgh, Scotland: The Scottish Government.

James, A. (2007). Giving voice to children's voices: Practices and problems, pitfalls and potentials. American Anthropologist, 109(2), 261-272. doi:10.1525/aa.2007.109.2.261

Kirkpatrick, R. (2012). Stories allways: “Tales for children's well-being”. Penicuik, Scotland: Stories Allways.

Krashen, S. D. (2004). The power of reading: Insights from research (2nd ed.). Westport, CT: Libraries Unlimited.

Lang, K., Bovenschen, I., Gabler, S., Zimmerman, J., Nowacki, K., Kliewer, J., \& Spangler, G. (2016). Foster children's attachment security in the first year after placement: A longitudinal study of predictors. Early Childhood Research Quarterly, 36, 269-280. doi:10.1016/j.ecresq.2015.12.019

Langhout, R. D., \& Thomas, E. (2010). Imagining participatory action research in collaboration with children: An introduction. American Journal of Community Psychology, 46(1-2), 60 66. doi:10.1007/s10464-010-9321-1

Leonard, M. (2015). The sociology of children, childhood and generation. London, UK: Sage.

Levy, R. (2011) Young children reading at home and at school. London, UK: Sage.

Mannay, D., Evans, R., Staples, E., Hallett, S., Roberts, L., Rees, A., \& Andrews, D. (2017) The consequences of being labelled 'looked-after': Exploring the educational experiences of looked-after children and young people in Wales. British Educational Research Journal, 43(4), 683-699. doi:10.1002/berj.3283 
International Journal of Child, Youth and Family Studies (2017) 8(3-4): 26-58

Marsh, J., Brookes, G., Hughes, J., Ritchie, L., Roberts, S., \& Wright, K. (2005). Digital beginnings: Young children's use of popular culture, media and new technologies. Sheffield, UK: Literacy Research Centre, University of Sheffield. Retrieved from http://www.digitalbeginnings.shef.ac.uk/DigitalBeginningsReport.pdf

Marsh, J., \& Millard, E. (2000). Literacy and popular culture: Using children's culture in the classroom. London, UK: Paul Chapman.

Mathers, S., Hardy, G., Clancy, C., Dixon, J., \& Harding, C. (2016) Starting out right: Early education and looked after children. London, UK: University of Oxford/Family and Childcare Trust.

Melhuish, E. (2010). Impact of the home learning environment on child cognitive development: Secondary analysis of data from 'Growing Up in Scotland'. Edinburgh, Scotland: Scottish Government.

Melhuish, E., Belsky, J., MacPherson, K., \& Cullis, A. (2011). The quality of group childcare settings used by 3-4 year old children in Sure Start Local Programme areas and the relationship with child outcomes (Research report DFE-RR068). London, UK: Department for Education.

Merriman, B., \& Guerin, S. (2006). Using children's drawings as data in child-centred research. Irish Journal of Psychology, 27(1-2), 48-57. doi:10.1080/03033910.2006.10446227

O’Higgins, A., Sebba, J., \& Luke, N. (2015). What is the relationship between being in care and the educational outcomes of children? An international systematic review. Oxford, UK: REES Centre, University of Oxford.

Oliver, C., Knight, A., \& Candappa, M. (2006). Advocacy for looked after children and children in need: Achievements and challenges. London, UK: Thomas Coram Research Unit.

O’Neil, K. E. (2011). Reading pictures: Developing visual literacy for greater comprehension. The Reading Teacher, 65(3), 214-223. doi:10.1002/TRTR.01026

Osbourne, C., Alfano, J., \& Winn, T. (2010). Paired reading as a literacy intervention for foster children. Adoption \& Fostering, 34(4), 17-26. doi:10.1177/030857591003400403

Palys, T. (2008). Purposive sampling. In L. M. Given (Ed.), The Sage encyclopedia of qualitative research methods (Vol. 2, pp. 697-698). Los Angeles, CA: Sage.

Paratore, J. R., \& Dougherty, S. (2011). Home differences and reading difficulty. In A. McGillFranzen \& R. L. Allington (Eds.). Handbook of reading disability research (pp. 93-109). New York, NY: Routledge. 
International Journal of Child, Youth and Family Studies (2017) 8(3-4): 26-58

Pears, K. C., \& Fisher, P. A. (2005). Emotion understanding and theory of mind among maltreated children in foster care: Evidence of deficits. Development and Psychopathology, 17(1), 47-56. doi:10.1017/S0954579405050030

Pears, K. C., Heywood, C. V., Kim, H. K., \& Fisher, P. A. (2011). Prereading deficits in children in foster care. School Psychology Review, 40(1), 140-148.

Poulton, L. (2012). Looked after children and literacy: A brief review. London, UK: National Literacy Trust.

Punch, S. (2002). Research with children: The same or different from research with adults? Childhood, 9(3), 321-341. doi:10.1177/0907568202009003005

Puffet, N. (2015, June). Massive rise in number of children in care under coalition. Children and Young People Now Magazine. Retrieved from https://www.cypnow.co.uk/cyp/news/1152176/massive-rise-in-number-of-children-in-care$\underline{\text { under-coalition }}$

Ratner, C. (2000) Agency and culture. Journal for the Theory of Social Behaviour, 30(4), 413434. doi:10.1111/1468-5914.00138

Rogoff, B. (1990). Apprenticeship in thinking: Cognitive development in social context. New York, NY: Oxford University Press.

Scottish Executive. (2008). Getting it right for every child: Proposals for action. Edinburgh, Scotland: Scottish Executive.

Scottish Government. (2010a). Literacy action plan: An action plan to improve literacy in Scotland. Edinburgh, Scotland: Author.

Scottish Government. (2010b). Supporting children's learning code of practice (Rev. ed.). Edinburgh, Scotland: Author.

Scottish Government. (2015a). Getting it right for looked after children and young people: Early engagement, early permanence and improving the quality of care [online]. Edinburgh, Scotland: Author. Retrieved from http://www.staf.scot/wpcontent/uploads/2016/11/Getting-It-Right-for-Looked-After-Children-and-YoungPeople.pdf

Scottish Government. (2015b). Tackling inequalities in the early years: Key messages from 10 years of the Growing Up in Scotland study. Edinburgh, Scotland: Author.

Scottish Government. (2016). Education outcomes for looked after children 2014/15. Edinburgh, Scotland: Author. Retrieved from http://www.gov.scot/Publications/2016/06/7455/8 
International Journal of Child, Youth and Family Studies (2017) 8(3-4): 26-58

Scottish Government. (2017). Children's social work statistics Scotland, 2015-16. Edinburgh, Scotland: Author. Retrieved from http://www.gov.scot/Publications/2017/03/6791

Scottish Parliament. (2012). 6th Report, 2012 (Session 4): Report on educational attainment of looked after children. Edinburgh, Scotland: Author. Retrieved from http://www.parliament.scot/parliamentarybusiness/CurrentCommittees/51538.aspx

Scottish Screen. (2009) Moving image education in Scotland. Glasgow, Scotland: Author http://www.scottishscreen.com/images/documents/moving image_2009.pdf

Sebba, J., Berridge, D., Luke, N., Fletcher, J., Bell, K., Strand, S., Thomas, S., ... O’Higgins, A. (2015). The educational progress of looked after children in England: Linking care and educational data. Bristol, UK: REES Centre, University of Bristol.

Simkiss, D. E., Stallard, N., \& Thorogood, M. (2013). A systematic literature review of the risk factors associated with children entering public care. Child: care, health and development, 39(5), 628-642. doi:10.1111/cch.12010

Skånfors, L. (2009). Ethics in child research: Children's agency and researchers' 'Ethical Radar' . Childhoods Today, 3(1), 1-22.

Smyth, J., \& Wrigley, T. (2013.) Living on the edge: Rethinking poverty, class and schooling. New York, NY: Peter Lang.

Stanovich, K. E. (1986). Matthew effects in reading: Some consequences of individual differences in the acquisition of literacy. Reading Research Quarterly, 21, 360-407.

Stevens, I, Kirkpatrick, R, \& McNicol, C. (2008). Improving literacy through storytelling in residential care. Scottish Journal of Residential Childcare, 7(2), 28-40. Retrieved from https://www.celcis.org/files/3814/3878/4517/SJRCC72_improving_literacy_through_storyt elling.pdf

Stewart, S. (2008). Assessing and developing self-esteem in very young, vunerable children. In K. Tisdall, J. M. Davis, \& M. Gallagher (Eds.), Researching with children and young people: Research design, methods and analysis (pp. 110-118). London, UK: Sage.

Sylva, K., Melhuish, E., Sammons, P., Siraj-Blatchford, I., and Taggart, B. (2004). The effective provision of pre-school education (EPPE) project. Technical paper 12. The final report: Effective pre-school education. London, UK: Institute of Education, University of London, Department for Education and Skills.

Thoburn, J., Chand, A., \& Procter, J. (2005). Child welfare services for minority ethnic families: The research reviewed. London, UK: Jessica Kingsley. 
International Journal of Child, Youth and Family Studies (2017) 8(3-4): 26-58

Tisdall, E. K. M., Davies, J. M., \& Gallagher, M. (2009). Researching with children and young people: Research, design, methods and analysis. London, UK: Sage.

Tisdall, E. K. M., \& Punch, S. (2012). Not so 'new'?: Looking critically at childhood studies. Children's Geographies, 10(3), 249-264. doi:10.1080/14733285.2012.693376

Tufford, L., \& Newman, P. (2012). Bracketing in qualitative research. Qualitative Social Work, 11(1), 80-96. doi:10.1177/1473325010368316

Valentine, G., Butler, R., \& Skelton, T. (2001). The ethical and methodological complexities of doing research with 'vulnerable' young people. Ethics, Place and Environment, 4(2), 119125. doi:10.1080/13668790123540

Vincent, J. (2004). Access to books and reading projects for young people in public care: The librarians' training kit - Final report. Nadderwater, Exeter: The Network. Retrieved from http://www.seapn.org.uk/uploads/files/PHF-Final-Report.pdf

Waller, T., \& Bitou, A. (2011). The sociology of childhood: Children's agency and participation in telling their own stories. In T. Waller, J. Whitmarsh, \& K. Clark (Eds.), Making sense of theory and practice in early childhood: The power of ideas (pp. 101-114). Maidenhead, UK: Open University Press.

Weinberger, J. (1996). A longitudinal study of children's early literacy experiences at home and later literacy development at home and school. Journal of Research in Reading, 19(1), 1424. doi:10.1111/j.1467-9817.1996.tb00083.x

Winter, K. (2006). Widening our knowledge concerning young looked after children: The case for research using sociological models of childhood. Child \& Family Social Work, 11(1), 55-64. doi:10.1111/j.1365-2206.2006.00385.x

Winter, K., Connolly, P., Bell, I., \& Ferguson, J. (2011). Evaluation of the effectiveness of Letterbox Club in improving educational outcomes among children aged 7-11 years in foster care in Northern Ireland. Belfast, Ireland: Centre for Effective Education, Queens University Belfast.

Wray, D., \& Lewis, M. (1997). Extending literacy: Children reading and writing non-fiction. London, UK: Routledge. 
International Journal of Child, Youth and Family Studies (2017) 8(3-4): 26-58

\section{Appendix 1}

\section{Part A: Family Profile}

1. Children in the home details
a. Child 1 (receiving letterbox parcel)
Age
Gender
b. Child 2
Age
Gender
c. Child 3
Age
Gender

2. School/Nursery/Playgroup etc.

Where applicable name of establishment
a. Child 1
b. Child 2
c. Child 3

Part B: Questionnaire

1. What do you think you will get out of the Letterbox Club?

2. Were the aims of the Letterbox Club explained to you at the start?

3. Are you looking forward to taking part/any reservations?

4. Are you a member of a library?
a. If yes, how often do you visit the library?
b. If yes, how many books do you take home on each visit?

5. How often do you read?

6. Do you share a book with the child? (E.g. Morning Daytime Evening Before bed)

7. a. How do you feel about reading

b. What kind of books do you like to read?

c. What is your favourite book that you have read recently?

d. Would you recommend it to a friend?

e. What would you say to them about the book?

f. Tell us everyone who reads to you - including your teacher!

8. Do you ever write things at home (for example, stories, diary, and notes)? Give details: 
International Journal of Child, Youth and Family Studies (2017) 8(3-4): 26-58

\section{Appendix 2}

\section{Children's Books}

Backshall, S. (2012). Deadly Factbook: Mammals. London: Orion.

Bradman, T. (2008). The Two Jacks. Edinburgh: Barrington Stoke.

Collodi, C. (2004). Pinocchio. London: Osborne.

Dahl, R. (1970). Fantastic Mr. Fox. London: George Allen \& Unwin.

Dahl, R. (1978). The Enormous Crocodile. London: Jonathan Cape.

Dahl, R. (1981). George's Marvellous Medicine. London: Jonathan Cape.

Don, L. (2012). Little Red Riding Hood. Oxford: Barefoot Books.

Dorling Kindersley. (2006). The Human Body (Eye Wonder). London: Dorling Kindersley.

Farrell, J. (2009). Manfred the Baddie. London: Quercus Children's Books.

King-Smith, D. (2012). The Finger Eater. London: Walker Books.

O’Connell, E. R. (2009). Ancient Egypt Sticker Book. London: British Museum Press.

McCall Smith, A. (2005). Akimbo and the Lions. Copenhagen: Egmont.

Noon, S. (2012). Story of the Titanic. London: Dorling Kindersley.

Rowling, J. K. (1997). Harry Potter and the Sorcerer's Stone. London: Bloomsbury.

Savage, S. (2006). Animal Neighbours: Owl. London: Wayland.

Simon, F. (2010). Horrid Henry Rocks. London: Orion.

Walker, R., \& Sharkey, N. (2006). Jack and the Beanstalk. Oxford: Barefoot Books. 